\title{
LANGUAGE ERRORS IN WARTA KOTA DAILY NEWSPAPER
}

\author{
Endang Wiyanti ${ }^{*}$ \\ Universitas Indraprasta PGRI \\ Yulian Dinihari \\ Universitas Indraprasta PGRI \\ Heppy Atmapratiwi \\ Universitas Indraprasta PGRI \\ *) Correspondences author: Jalan Nangka No. 58 C Tanjung Barat, Jagakarsa, Jakarta Selatan, 12530, Indonesia; \\ e-mail: endang.wiyanti@unindra.ac.id
}

\begin{abstract}
Various features presented in the newspaper will add information to the reader. With increasing insight every day, they will increasingly be critical of the conditions that occur around found in writing in the newspaper. The language errors that occur are indicative of a lack of understanding of Bahasa. The researcher used a qualitative research approach with a type of descriptive study to be more focused and in accordance with the research objectives. The subject of this research is Warta Kota daily newspaper from October-December 2018 with the object of research being a mistake in various features of Warta Kota daily newspaper. Based on the data, errors analysis based on the largest to the smallest were Morphological errors (34.91\%); Syntax error (16.04\%); Error of Absorption Element (12.26); Word Writing errors (11.32\%); Phonological errors (8.49\%); Punctuation Writing Error (6.60\%); Particle / Word Selection Writing errors and Word Combined Writing errors (3.77\%); Front Word Writing errors (1.89\%); and Error in the Use of Letters $(0.94 \%)$.
\end{abstract}

Keyword: Error Analysis, Newspaper

Article History: Received: 25/05/2021; Revised: 11/06/2021; Accepted: 11/06/2021; Published: 30/06/2021.

How to Cite (MLA 7 ${ }^{\text {th }}$ : Wiyanti, Endang, Yulian Dinihari, and Heppy Atmapratiwi. "Language Errors in Warta Kota Daily Newspaper." Hortatori Jurnal Pendidikan Bahasa dan Sastra Indonesia 5.1 (2021): 28-37. Print/Online. Copyrights Holder: Endang Wiyanti, Yulian Dinihari, Heppy Atmapratiwi. First Publication: Hortatori Jurnal Pendidikan Bahasa dan Sastra Indonesia (2017).

\section{Pendahuluan}

Saat ini keberadaan media massa berkembang sangat pesat. Media massa khususnya media cetak menjadi pilihan untuk mencari informasi dan berita. Sebagian besar masyarakat lebih memilih surat kabar dibanding portal berita daring karena validitasnya dianggap lebih tinggi (Sutrisna). Surat kabar atau koran yang terbit setiap hari dibaca oleh masyarakat dari lapisan yang berbeda. Dari surat kabar kita akan mendapatkan segala informasi yang berhubungan dengan kehidupan, baik lokal, nasional maupun internasional.

Surat kabar sebagai sarana penyampaian informasi memiliki pengaruh baik terhadap perkembangan cara berpikir masyarakat. Saat wawasan mereka meningkat setiap hari, mereka akan menjadi semakin kritis terhadap hal-hal yang terjadi di sekitar mereka. Berbagai informasi yang dihadirkan dalam surat kabar akan menambah informasi bagi pembaca.

Namun pada kenyataannya informasi tersebut bisa saja menjadi tidak utuh apabila masih ditemukan kesalahan penulisan dalam surat kabar. Seorang wartawan tidak hanya harus mampu mencari berita tetapi juga harus pandai merangkai kemampuan untuk menuangkan seluruh informasi menggunakan kata-kata 
yang menarik sehingga pembacanya memahami informasi yang akan disampaikan (Chasanah et al.). Kesalahan bahasa yang terjadi karena beberapa faktor, yaitu tingkat persaingan yang tinggi di antara surat kabar yang ada di Indonesia. Hal ini menyebabkan prosesnya berjalan dengan cepat dan penyunting dianggap tidak teliti dalam menyunting berita sebelum diterbitkan (Sutrisna). Selain itu, faktor lainnya yaitu banyaknya wartawan yang belum memahami kaidah kebahasaan dalam keterampilan menulis berita (Wahyuni). Bahasa Indonesia selalu berkembang dari waktu ke waktu, dan tidak dapat dipungkiri hal tersebut harus dapat diikuti dengan benar oleh masyarakat. Dalam hal ini surat kabar sebagai salah satu media massa untuk menyampaikan informasi kepada masyarakat harus mampu memberikan contoh penggunaan bahasa Indonesia yang baik dan benar.

Kesalahan yang masih sering ditemukan diantaranya penulisan ejaan, seperti huruf kapital, tanda baca titik, koma, penulisan kata gabung, kata ulang, penulisan partikel pun, dan sebagainya. Selain itu kesalahan morfologi seperti pemajemukan kata dasar dan penambahan imbuhan juga masih sering terjadi. Dalam kesalahan sintaksis yang berkaitan dengan makna dan semantik yang mengkaji kesalahan dalam kalimat pada surat kabar masih ditemukan pula (Nisa).

Kesalahan berbahasa adalah penyimpangan yang dilakukan dalam kegiatan berbahasa, sedangkan analisis kesalahan berbahasa adalah proses mendata temuan kesalahan, mengidentifikasi jenis-jenis kesalahannya, mengklasifikasikan sifat-sifat kesalahannya, serta menentukan sumber dan penyebab kesalahan berbahasa (Wiyanti et al.). Kesalahan berbahasa adalah pemakaian suatu bahasa yang tidak sesuai dengan ketentuan bahasa, sedangkan penggunaan suatu bahasa yang tidak sesuai ketentuan bahasa tapi tidak disadari dan menjadi kebiasaan disebut kekeliruan berbahasa (Rais et al.). Penyebab dari kesalahan bahasa adalah faktor kompetensi, yaitu kesalahan yang disebabkan karena seseorang belum memahami sistem linguistik bahasa yang digunakan (Sebayang and Sofyan)

Menurut Dulay, Burt, dan Krashen (1982) wilayah taksonomi kesalahan berbahasa ada 4 macam. salah satunya taksonomi kategori linguistik yakni kesalahan tataran fonologi, morfologi dan sintaksis, semantik dan kata, serta kesalahan tataran wacana (Nurwicaksono and Amelia). Fonologi adalah kajian bahasa yang mempelajari bunyi (fonem) bahasa yang diproduksi alat ucap manusia. Tataran kesalahan fonologi terjadi pada pelafalan bunyi (fonem) yang pengucapannya tidak sesuai dengan kaidah bahasa Indonesia (Alber and Hermaliza). Selanjutnya morfologi atau tata kata memelajari asal-usul bentuk kata dan pengaruh perubahan bentuk kata terhadap golongan dan arti kata. Tataran kesalahan dalam morfologi mencakup kesalahan afiksasi, reduplikasi, dan pemajemukan (Utami). Kesalahan bahasa yang sering terjadi pada tataran sintaksis yaitu kalimat yang tidak memiliki subjek, objek, predikat, subjek ganda, tidak ada sisipan antara predikat dan objek, kalimat tidak logis, kalimat ambigu, konjungsi yang hilang serta berlebihan, penggunaan istilah dalam bahasa asing, urutan tidak pararel, serta kata tanya yang tidak perlu (Nurwicaksono and Amelia). Kemudian kesalahan semantik terjadi karena pemilihan diksi yang kurang tepat sehingga membuat maknanya ambigu, dan kesalahan tataran wacana yang lencakup kohesi dan koherensi.

Pada penelitian sebelumnya dalam artikel Kesalahan Morfologi dalam Keterampilan Menulis karangan Narasi Siswa SMK Swasta Ceger Jakarta Timur (Nafilah et al.) fokus penelitiannya sama seperti penelitian ini, yaitu kesalahan morfologi pada karangan narasi yang dibuat oleh siswa SMK. Perbedaannya dalam penelitian ini kami tertarik untuk mengadakan penelitian mengenai kesalahan berbahasa yang meliputi kesalahan Morfologi, kesalahan Sintaksis, kesalahan Penulisan Unsur Serapan, kesalahan Penulisan Kata, kesalahan Fonologi, kesalahan Penulisan Tanda Baca, kesalahan Penulisan Partikel/Pemilihan Kata dan kesalahan, Penulisan Gabungan Kata, kesalahan Penulisan Kata Depan, dan kesalahan Pemakaian Huruf pada media cetak. Berawal dari ketertarikan penulis pada bentuk feature yang mengandung banyak kesalahan berbahasa ini, penulis berusaha mendeskripsikan kesalahan yang terjadi. Dalam hal ini penulis mengambil sampel dari Harian Warta Kota. Warta Kota merupakan salah satu produk dari PT Metrogema Media Nusantara yang merupakan anak perusahaan dari Kelompok Usaha Kompas Gramedia. Warta kota didirikan pada 1998 yang dominasi beritanya terkait permasalahan metropolitan khususnya daerah Jakarta, Bogor, Depok, Tangerang, dan Bekasi (Jabodetabek) sebanyak 80\%. Koran ini sengaja dijadikan media khas untuk dijadikan panduan oleh masyarakat dalam memeroleh informasi terkait hak dan kewajiban sebagai warga Jabodetabek dan sekitarnya (Nasim).

Peneliti akan mendeskripsikan serta memperbaiki kesalahan-kesalahan yang terjadi, terutama pada bentuk bahasa dan penulisannya. 


\section{Metode}

Peneliti menggunakan pendekatan penelitian kualitatif dengan jenis studi deskriptif agar lebih fokus dan sesuai tujuan penelitian. Alasan yang mendorong peneliti menggunakan jenis penelitian deskriptif adalah untuk mengetahui lebih mendalam dalam menjabarkan kesalahan-kesalahan berbahasa dalam surat kabar harian Warta Kota periode Oktober-Desember 2018 dengan objek penelitian adalah kesalahan dalam berbagai feature surat kabar harian Warta Kota.

Teknik pengumpulan data dalam penelitian ini dilakukan dengan teknik observasi, teknik Focus Group Discussion ( $F G D$ ), dan teknik dokumen. Analisis data dalam penelitian ini menggunakan pendekatan studi kasus, dengan hipotesis masih terdapat banyak kesalahan dalam media cetak. Dalam hal ini peneliti akan mendeskripsikan hasil temuan kesalahan yang terjadi pada surat kabar harian Warta Kota dan memberikan saran sebagai sebuah solusi. Analisis data dalam penelitian kualitatif dilakukan pada saat pengumpulan data berlangsung dan setelah selesai pengumpulan data dalam periode tertentu. Secara lengkap, kerangka model penelitian ini yaitu pengumpulan data, klasifikasi data, interpretasi data, dan menarik simpulan.

\section{Hasil dan Diskusi}

\section{Hasil}

Berikut ini akan dipaparkan temuan dalam surat kabar harian Warta Kota dalam bentuk tabel.

Tabel 1. Temuan Kesalahan Berbahasa pada Surat Kabar Harian Warta Kota

\begin{tabular}{|c|c|c|c|c|c|c|c|c|c|c|c|c|}
\hline \multirow{2}{*}{ No } & \multirow{2}{*}{ Data } & \multicolumn{10}{|c|}{ Kesalahan } & \multirow[t]{2}{*}{ Perbaikan } \\
\hline & & 1 & 2 & 3 & 4 & 5 & 6 & 7 & 8 & 9 & 10 & \\
\hline 1. & $\begin{array}{l}\text { Tapi, saat itu juga bidan Yn ngomong } \\
\text { kalau tanpa paket bidan, biaya } \\
\text { persalinan dari hari Sabtu hingga Rabu } \\
\text { menyentuh harga } 17,5 \text { juta. } \\
(02 / 10 / 2018)\end{array}$ & & & & $\sqrt{ }$ & & & & & & & $\begin{array}{l}\text { Akan tetapi, saat itu juga bidan Yn } \\
\text { berkata kalau tanpa paket bidan, } \\
\text { biaya persalinan dari hari Sabtu } \\
\text { hingga Rabu menyentuh harga } 17,5 \\
\text { juta. }\end{array}$ \\
\hline 2. & $\begin{array}{l}\text { Sekertaris Pelaksanaan Pengadaan } \\
\text { Tanah Proyek Tol Serpong-Cinere } \\
(02 / 10 / 2018)\end{array}$ & & $\sqrt{ }$ & & & & & $\sqrt{ }$ & & & & $\begin{array}{l}\text { Sekretaris Pelaksanaan Pengadaan } \\
\text { Tanah Proyek Tol Serpong--Cinere }\end{array}$ \\
\hline 3. & $\begin{array}{l}\text { Edi Sunaryo, salah satu penghuni } \\
\text { rumah kontrakan tampak shock. } \\
(02 / 10 / 2018)\end{array}$ & & & & & & $\sqrt{ }$ & & & & & $\begin{array}{l}\text { Edi Sunaryo, salah satu penghuni } \\
\text { rumah kontrakan tampak shock. }\end{array}$ \\
\hline 4. & $\begin{array}{l}\text { Jadi untuk kesehatan cesar lagi. } \\
(02 / 10 / 2018)\end{array}$ & & & & & & $\sqrt{ }$ & & & & & Jadi untuk kesehatan sesar lagi. \\
\hline 5. & $\begin{array}{l}\text { Jadinya lagi pada ngumpul di sana. } \\
(02 / 10 / 2018)\end{array}$ & & & & & & & & & $\sqrt{ }$ & & $\begin{array}{l}\text { Jadinya lagi pada berkumpul di } \\
\text { sana. }\end{array}$ \\
\hline 6. & $\begin{array}{l}\text { Aku sering dijahilin soalnya. } \\
(02 / 10 / 2018)\end{array}$ & & & & & & & & & $\sqrt{ }$ & & Aku sering dijahili soalnya. \\
\hline 7. & $\begin{array}{l}\text { Makanya aku nggak berani ngaca, } \\
\text { ngobrol sama orang pun mereka } \\
\text { enggak lihat aku, mereka nunduk. } \\
(02 / 10 / 2018)\end{array}$ & & & & & & & & & $\sqrt{ }$ & & $\begin{array}{l}\text { Makanya aku tidak berani mengaca, } \\
\text { mengobrol sama orang pun mereka } \\
\text { tidak melihat aku, mereka } \\
\text { menunduk. }\end{array}$ \\
\hline 8. & $\begin{array}{l}\text { Yang dipuji ruoanya malah balik } \\
\text { memuji Ali. }(02 / 10 / 2018)\end{array}$ & & $\sqrt{ }$ & & & & & & & & & $\begin{array}{l}\text { Yang dipuji rupanya malah balik } \\
\text { memuji Ali. }\end{array}$ \\
\hline 9. & $\begin{array}{l}\text { Saya tanam cabe, terong dan bawang } \\
\text { merah. }(02 / 10 / 2018)\end{array}$ & & & & & & $\sqrt{ }$ & & & $\sqrt{ }$ & & $\begin{array}{l}\text { Saya menanam cabai, terong, dan } \\
\text { bawang merah. }\end{array}$ \\
\hline 10. & $\begin{array}{l}\text { Menurut hasil survey Employee Skills } \\
\text { yang dilakukan Bank Dunia tahun } \\
2008 .(02 / 10 / 2018)\end{array}$ & & & & & & $\sqrt{ }$ & & & & & $\begin{array}{l}\text { Menurut hasil survei Employee } \\
\text { Skills yang dilakukan Bank Dunia } \\
\text { tahun } 2008 \ldots .\end{array}$ \\
\hline 11. & $\begin{array}{l}\text { Kemendikbud-Tanoto Foundation } \\
\text { Luncurkan Program PINTAR } \\
(02 / 10 / 2018)\end{array}$ & & & & & & & $\sqrt{ }$ & & $\sqrt{ }$ & & $\begin{array}{l}\text { Kemendikbud-Tanoto Foundation- } \\
\text { - Meluncurkan Program PINTAR }\end{array}$ \\
\hline 12. & $\begin{array}{l}\text { KPR Mikro BTN Gandeng Kampus } \\
(02 / 10 / 2018)\end{array}$ & & & & & & & & & $\sqrt{ }$ & & $\begin{array}{l}\text { KPR Mikro BTN Menggandeng } \\
\text { Kampus }\end{array}$ \\
\hline 13. & $\begin{array}{l}\text { Jadinya aku juga nggak mau ngaca. } \\
(02 / 10 / 2018)\end{array}$ & & & & & & & & & $\sqrt{ }$ & & Jadinya aku juga tidak mau berkaca. \\
\hline 14. & Yah jahilin biasa aja. $(02 / 10 / 2018)$ & & & & & & & & & $\sqrt{ }$ & & Yah menjahili biasa aja. \\
\hline 15. & $\begin{array}{l}\text { Ia pernyataannya dalam bahasa } \\
\text { Indonesia. }(02 / 10 / 2018)\end{array}$ & & & & & & & & & $\sqrt{ }$ & & $\begin{array}{l}\text { Ia menyatakannya dalam bahasa } \\
\text { Indonesia. }\end{array}$ \\
\hline 16. & $\begin{array}{l}\text {.. hingga membangun kembali Palu } \\
\text { seperti sedia kala. }(02 / 10 / 2018)\end{array}$ & & & & & $\sqrt{ }$ & & & & & & $\begin{array}{l}\text {... hingga membangun kembali Palu } \\
\text { seperti sediakala. }\end{array}$ \\
\hline 17. & $\begin{array}{l}\text { Di depan rumah, sebuah tenda putih } \\
\text { berdiri dan beberapa karangan bunga } \\
\text { duka cita terpajang. }(02 / 10 / 2018)\end{array}$ & & & & & $\sqrt{ }$ & & & & & & $\begin{array}{l}\text { Di depan rumah, sebuah tenda putih } \\
\text { berdiri dan beberapa karangan bunga } \\
\text { dukacita terpajang. }\end{array}$ \\
\hline
\end{tabular}




\begin{tabular}{|c|c|c|c|c|c|c|c|c|c|c|c|c|}
\hline \multirow{2}{*}{ No } & \multirow{2}{*}{ Data } & \multicolumn{10}{|c|}{ Kesalahan } & \multirow[t]{2}{*}{ Perbaikan } \\
\hline & & 1 & 2 & 3 & 4 & 5 & 6 & 7 & 8 & 9 & 10 & \\
\hline 18. & $\begin{array}{l}\text { Senin pagi kemarin, pada hari keempat } \\
\text { pasca-gempa, belum ada bantuan } \\
\text { sama sekali dari pemerintah. } \\
(02 / 10 / 2018)\end{array}$ & & & & & $\sqrt{ }$ & & & & & & $\begin{array}{l}\text { Senin pagi kemarin, pada hari } \\
\text { keempat pascagempa, belum ada } \\
\text { bantuan sama sekali dari } \\
\text { pemerintah. }\end{array}$ \\
\hline 19. & $\begin{array}{l}\text { Yang penyerapannya ma-sih rendah } \\
\text { seperti Dinas Peru-mahan, Dinas } \\
\text { Sumber Daya air, Dinar Bina Marga. } \\
(02 / 10 / 2018)\end{array}$ & & $\begin{array}{l}\sqrt{ } \\
\sqrt{ }\end{array}$ & & & & & & & & & $\begin{array}{l}\text { Yang penyerapannya masih rendah } \\
\text { seperti Dinas Perumahan, Dinas } \\
\text { Sumber Daya air, Dinar Bina Marga. }\end{array}$ \\
\hline 20. & Terseok $(5 / 11 / 2018)$ & & $\sqrt{ }$ & & & & & & & & & Terseok-seok \\
\hline 21. & Setimnya $(5 / 11 / 2018)$ & & & & $\sqrt{ }$ & & & & & & & Beregu \\
\hline 22. & Lalu-lintas (5/11/2018) & & $\sqrt{ }$ & & & & & & & & & Lalu lintas \\
\hline 23. & Syok $(5 / 11 / 2018)$ & & & & $\sqrt{ }$ & & & & & & & Trauma \\
\hline 24. & $\begin{array}{l}\text { Tambahan tersebut terdiri dari } \\
\text { penambahan } 197 \text { frekuensi } \\
\text { penerbangan Garuda Indonesia dan } \\
216 \text { frekuensi penerbangan Citilink. } \\
(5 / 11 / 2018)\end{array}$ & & & & & & & & & & $\sqrt{ }$ & $\begin{array}{l}\text { Tambahan tersebut terdiri dari } 197 \\
\text { frekuensi penerbangan Garuda } \\
\text { Indonesia dan } 216 \text { frekuensi } \\
\text { penerbangan Citilink. }\end{array}$ \\
\hline 25. & Press release $(5 / 11 / 2018)$ & & & & & & $\sqrt{ }$ & & & & & Press release \\
\hline 26. & $\begin{array}{l}\text { Belum masuk ke daerah-daerah yang } \\
\text { masyarakatnya unbankable atau } \\
\text { belum tersentuh perbankan. } \\
(10 / 11 / 2018)\end{array}$ & & & & & & $\sqrt{ }$ & & & & & $\begin{array}{l}\text { Belum masuk ke daerah-daerah yang } \\
\text { masyarakatnya unbankable atau } \\
\text { belum tersentuh perbankan }\end{array}$ \\
\hline 27. & $\begin{array}{l}\text { Ada bekas gedung sekolah yang } \\
\text { terimbas 'regrouping'. }(15 / 11 / 2018)\end{array}$ & & & & & & & $\sqrt{ }$ & & & & $\begin{array}{l}\text { Ada bekas gedung sekolah yang } \\
\text { terimbas " } \\
\text { "regrouping" }\end{array}$ \\
\hline 28. & $\begin{array}{l}\text { PT Kereta Api Indonesia (KAI) } \\
\text { memastikan percepatan proses } \\
\text { pemindahan gate di stasiun Tanah } \\
\text { Abang, Jakarta Pusat. (15/11/2018) }\end{array}$ & & & & & & $\sqrt{ }$ & & & & & $\begin{array}{l}\text { PT Kereta Api Indonesia (KAI) } \\
\text { memastikan percepatan proses } \\
\text { pemindahan gate di stasiun Tanah } \\
\text { Abang, Jakarta Pusat. }\end{array}$ \\
\hline 29. & $\begin{array}{l}\text { Skybridge Tanah Abang akan } \\
\text { diresmikan }(15 / 12 / 2018)\end{array}$ & & & & & & $\sqrt{ }$ & & & & & $\begin{array}{l}\text { Skybridge Tanah Abang akan } \\
\text { diresmikan }\end{array}$ \\
\hline 30. & Mengganggur (25/11/2018) & & $\sqrt{ }$ & & & & & & & & & Menganggur \\
\hline 31. & $\begin{array}{l}\text { Tadi ada petugas minta sample } \\
(25 / 12 / 2018)\end{array}$ & & & & & & $\sqrt{ }$ & & & & & Tadi ada petugas minta sampel \\
\hline 32. & $\begin{array}{l}\text { Larangan sudah jelas terpasangan di } \\
\text { dua titik }(25 / 11 / 2018)\end{array}$ & & & & & & & & & $\sqrt{ }$ & & $\begin{array}{l}\text { Larangan sudah jelas terpasang di } \\
\text { dua titik }\end{array}$ \\
\hline 33. & $\begin{array}{l}\text { Reino Barack (34) bekas kekasih } \\
\text { bintang film Luna Maya ( } 35) \\
(25 / 11 / 2018)\end{array}$ & & & & $\sqrt{ }$ & & & & & & & $\begin{array}{l}\text { Reino Barack (34) mantan kekasih } \\
\text { bintang film Luna Maya ( } 35 \text { ) }\end{array}$ \\
\hline 34. & Drainase Vertical (25/11/2018) & & & & & & $\sqrt{ }$ & & & & & Drainase Vertikal \\
\hline 35. & Uji coba system tersebut $(25 / 11 / 2018)$ & & & & & & $\sqrt{ }$ & & & & & Uji coba sistem tersebut \\
\hline 36. & $\operatorname{Beach}(6 / 12 / 2018)$ & & & & & & $\sqrt{ }$ & & & & & Beach \\
\hline 37. & Tapi (6/12/2018) & & & $\sqrt{ }$ & & & & & & & & Akan tetapi \\
\hline 38. & ‘ ungkap (6/12/2018) & & & & & & & $\sqrt{ }$ & & & & “ ungkap \\
\hline 39. & Rerekonsiliasi (6/12/2018) & & $\sqrt{ }$ & & & & & & & & & Rekonsiliasi \\
\hline 40. & Base camp $(6 / 12 / 2018)$ & & & & & & $\sqrt{ }$ & & & & & Base camp \\
\hline 41. & Karena itu (6/12/2018) & & & $\sqrt{ }$ & & & & & & & & Oleh karena itu \\
\hline 42. & E- KTP $(6 / 12 / 2018)$ & & & & & & & $\sqrt{ }$ & & & & $E$-KTP \\
\hline 43. & Di klaim $(6 / 12 / 2018)$ & & $\sqrt{ }$ & & & & & & & & & Diklaim \\
\hline 44. & dispendukcapil (6/12/2018) & $\sqrt{ }$ & & & & & & & & & & Dispendukcapil \\
\hline 45. & Langsungrekaman $(6 / 12 / 2018)$ & & $\sqrt{ }$ & & & & & & & & & Langsung rekaman \\
\hline 46. & Sesaji $(6 / 12 / 2018)$ & & $\sqrt{ }$ & & & & & & & & & Sesajen/sesajian \\
\hline 47. & Di diami $(6 / 12 / 2018)$ & & $\sqrt{ }$ & & & & & & & & & didiami \\
\hline 48. & $\begin{array}{l}\text { Pengeroyok Ngaku Dipukul Duluan } \\
(15 / 12 / 2018)\end{array}$ & & & & & & & & $\sqrt{ }$ & $\sqrt{ }$ & & $\begin{array}{l}\text { Pengeroyok Mengaku Dipukul } \\
\text { Duluan }\end{array}$ \\
\hline 49. & $\begin{array}{l}\text { Politisi Kebon Sirih Siapkan Empat } \\
\text { Perda Inisiatif di 2019. (15/12/2018) }\end{array}$ & & & & & & & & $\sqrt{ }$ & $\sqrt{ }$ & & $\begin{array}{l}\text { Politisi Kebon Sirih Menyiapkan } \\
\text { Empat Perda Inisiatif di } 2019\end{array}$ \\
\hline 50. & $\begin{array}{l}\text { Koja Punya TPS Tanpa Bau Busuk. } \\
(15 / 12 / 2018)\end{array}$ & & & & & & & & & $\sqrt{ }$ & & $\begin{array}{l}\text { Koja Mempunyai TPS Tanpa Bau } \\
\text { Busuk }\end{array}$ \\
\hline 51. & $\begin{array}{l}\text { Pengurus Masjid Akui Kesulitan } \\
\text { Dapat Air Bersih. (15/12/2018) }\end{array}$ & & & & & & & & & $\sqrt{ }$ & & $\begin{array}{l}\text { Pengurus Masjid Mengakui } \\
\text { Kesulitan Dapat Air Bersih }\end{array}$ \\
\hline 52. & $\begin{array}{l}\text { Pemkot Depok Ngotot Pagari Pasar } \\
\text { Cisalak. }(15 / 12 / 2018)\end{array}$ & & & & & & & & $\sqrt{ }$ & $\sqrt{ }$ & & $\begin{array}{l}\text { Pemkot Depok Ngotot Memagari } \\
\text { Pasar Cisalak. }\end{array}$ \\
\hline 53. & $\begin{array}{l}\text { Jamin Seluruh Warga Tangsel } \\
\text { Tercover } \text { BPJS. }(15 / 12 / 2018)\end{array}$ & & & & & & & & & $\sqrt{ }$ & & $\begin{array}{l}\text { Menjamin Seluruh Warga Tangsel } \\
\text { Tercover BPJS. }\end{array}$ \\
\hline 54. & $\begin{array}{l}\text { BPBD Bogor Salurkan Terpal dan } \\
\text { Asbes. }(15 / 12 / 2018)\end{array}$ & & & & & & & & & $\sqrt{ }$ & & $\begin{array}{l}\text { BPBD Bogor Menyalurkan Terpal } \\
\text { dan Asbes }\end{array}$ \\
\hline 55. & $\begin{array}{l}\text { Sementara Tambal Pakai Karung } \\
\text { Pasir. (15/12/2018) }\end{array}$ & & & & & & & & & $\sqrt{ }$ & & $\begin{array}{l}\text { Sementara Menambal Pakai Karung } \\
\text { Pasir }\end{array}$ \\
\hline 56. & $\begin{array}{l}\text { Milly \& Mamet Rasakan Kenyamanan } \\
\text { dan Ketangguhan Mistubishi } \\
\text { XPANDER. (15/12/2018) }\end{array}$ & & & & & & & & & $\sqrt{ }$ & & $\begin{array}{l}\text { Milly \& Mamet Merasakan } \\
\text { Kenyamanan dan Ketangguhan } \\
\text { Mistubishi XPANDER }\end{array}$ \\
\hline
\end{tabular}




\begin{tabular}{|c|c|c|c|c|c|c|c|c|c|c|c|c|}
\hline \multirow{2}{*}{ No } & \multirow{2}{*}{ Data } & \multicolumn{10}{|c|}{ Kesalahan } & \multirow[t]{2}{*}{ Perbaikan } \\
\hline & & 1 & 2 & 3 & 4 & 5 & 6 & 7 & 8 & 9 & 10 & \\
\hline \multirow[t]{3}{*}{57.} & Jokowi Tak Ingin Instan "Kalau Mau & & & & & & & & & & & Jokowi Tak Ingin Instan "Kalau \\
\hline & Nyenangkan Semua, Tinggal Tebar & & & & & & & & $y$ & $y$ & & Mau Menyenangkan Semua, Tinggal \\
\hline & $\begin{array}{l}\text { BLT" } \\
(20 / 12 / 2018)\end{array}$ & & & & & & & & & & & Tebar BLT" \\
\hline \multirow[t]{2}{*}{58.} & Besok, KPU Umumkan DPT. & & & & & & & & & $\sqrt{ }$ & & Recol KPU Monumuman DPT \\
\hline & $(20 / 12 / 2018)$ & & & & & & & & & $\mathrm{v}$ & & Desok, КPU мие gититкап DP \\
\hline \multirow[t]{2}{*}{59.} & Didakwa Korupsi Rp 45 M, Bupati & & & & & & & & $\sqrt{ }$ & $\sqrt{ }$ & & Didakwa Korupsi Rp 45 M, Bupati \\
\hline & Labuhanbatu Nangis. $(20 / 12 / 2018)$ & & & & & & & & $\mathrm{v}$ & $\mathrm{V}$ & & Labuhanbatu Menangis \\
\hline \multirow[t]{2}{*}{60.} & PKB Usung Putra Kiai, PPP Usung & & & & & & & & & J & & PKB Mengusung Putra Kiai, PPP \\
\hline & Senator. $(20 / 12 / 2018)$ & & & & & & & & & $\mathrm{V}$ & & Mengusung Senator \\
\hline \multirow[t]{2}{*}{61.} & Polri Pamerin Tersangka & & & & & & & & ل & $\sqrt{1}$ & & Polri Memamerkan Tersangka \\
\hline & Pengeroyokan TNI. (20/12/2018) & & & & & & & & & & & Pengeroyokan TNI \\
\hline \multirow[t]{2}{*}{62.} & Wow... Nenek 102 Tahun Pecahin & & & & & & & & $\checkmark$ & $\sqrt{ }$ & & Wow... Nenek 102 Tahun \\
\hline & Rekor Terjun Payung. (20/12/2018) & & & & & & & & $\mathrm{v}$ & $v$ & & Memecahkan Rekor Terjun Payung \\
\hline \multirow[t]{2}{*}{63.} & Warga Keluhkan Pembangunan Tower & & & & & & & & & $\sqrt{ }$ & & Warga Mengeluhkan Pembangunan \\
\hline & Sutet. $(20 / 12 / 2018)$ & & & & & & & & & $\mathrm{v}$ & & Tower Sutet \\
\hline 64. & $\begin{array}{l}\text { Jose Mourinho Nyindir The Reds Soal } \\
\text { Trofi. }(20 / 12 / 2018)\end{array}$ & & & & & & & & $\sqrt{ }$ & $\sqrt{ }$ & & $\begin{array}{l}\text { Jose Mourinho Menyindir The Reds } \\
\text { Soal Trofi }\end{array}$ \\
\hline 65. & Sejak duduk di bangku kuliah 2006 & & & & & & & & & & & Sejak duduk di bangku kuliah 2006 \\
\hline & silam, guru SD Islam Al Fauzien ini & & & & & & & & & & & silam, guru SD Islam Al Fauzien ini \\
\hline & sudah memulai karier pertamanya. & & & & & & & & & & & sudah memulai karier pertamanya, \\
\hline & Yakni, menjadi pengajar di tempat & & & & & & & & & & $\sqrt{ }$ & yakni menjadi pengajar di tempat \\
\hline & kursus untuk memenuhi kebutuhan & & & & & & & & & & & kursus untuk memenuhi kebutuhan \\
\hline & $\begin{array}{l}\text { selama menjalankan masa kuliah. } \\
(19 / 12 / 2018)\end{array}$ & & & & & & & & & & & selama menjalankan masa kuliah. \\
\hline 66. & Dengan peserta yang mengikuti & & & & & & & & & & & Peserta yang mengikuti kurang lebih \\
\hline & kurang lebih 1.000 peserta dari tingkat & & & & & & & & & & $\sqrt{1}$ & 1.000 orang dari tingkat SD- \\
\hline & $\begin{array}{l}\text { SD-Perguruan Tinggi se-jabodetabek. } \\
(19 / 12 / 2018)\end{array}$ & & & & & & & & & & $v$ & Perguruan Tinggi se-jabodetabek. \\
\hline 67. & Namun, perguruan tinggi lama yang & & & & & & & & & & & Namun, perguruan tinggi lama yang \\
\hline & tidak bermutu, akan dilakukan merger. & & & & & & & & & & & tidak bermutu, akan dilakukan \\
\hline & Sedangkan yang tidak melakukan & & & & & & & & & & $\sqrt{ }$ & merger, sedangkan yang tidak \\
\hline & $\begin{array}{l}\text { pembelajaran dengan baik akan } \\
\text { ditutup. }(19 / 12 / 2018)\end{array}$ & & & & & & & & & & & $\begin{array}{l}\text { melakukan pembelajaran dengan } \\
\text { baik akan ditutup. }\end{array}$ \\
\hline 68. & Menteri Nasir membeberkan, ini & & & & & & & & & & & Menteri Nasir membeberkan, ini \\
\hline & namanya dinamika pendidikan. Tidak & & & & & & & & & & & namanya dinamika pendidikan. \\
\hline & berarti kebijakan merger, tidak boleh & & & & & & & & & & $\sqrt{ }$ & Bukan berarti kebijakan merger \\
\hline & $\begin{array}{l}\text { mendirikan perguruan tinggi baru. } \\
(19 / 12 / 2018)\end{array}$ & & & & & & & & & & & $\begin{array}{l}\text { tidak boleh mendirikan perguruan } \\
\text { tinggi baru. }\end{array}$ \\
\hline 69. & Junaedi Sitorus menambahkan, dengan & & & & & & & & & & & Junaedi Sitorus menambahkan, \\
\hline & dibentuknya DPW PPKLI DKI & & & & & & & & & & & dengan dibentuknya DPW PPKLI \\
\hline & Jakarta, dia berharap agar para anggota & & & & & & & & & & $\sqrt{ }$ & DKI Jakarta, dia berharap agar \\
\hline & PKL yang ada di DKI Jakarta dapat & & & & & & & & & & & anggota PKL dapat terorganisasi \\
\hline & terorganisir dan tertera di bawah & & & & & & & & & & & dan tertera di bawah naungan \\
\hline 70. & Lembaga Pelaksana Pelatihan (LPP) & & & & & & & & & & & Lembaga Pelaksana Pelatihan (LPP) \\
\hline & Al Fattah mengadakan Workshop & & & & & & & & & & & Al Fattah mengadakan seminar \\
\hline & Peningkatan Mutu Lembaga yang & & & & & & & & & & & Peningkatan Mutu Lembaga yang \\
\hline & membahas tentang kepemimpinan, & & & & & & & & & & $\sqrt{ }$ & membahas kepemimpinan, \\
\hline & Manajemen PAUD, dan & & & & & & & & & & & Manajemen PAUD, dan \\
\hline & kewirausahaan di Aula Gedung & & & & & & & & & & & kewirausahaan di Aula Gedung \\
\hline & $\begin{array}{l}\text { Perpustakaan Kota Depok. } \\
(19 / 12 / 2018)\end{array}$ & & & & & & & & & & & Perpustakaan Kota Depok. \\
\hline 71. & Para pemain top Indonesia yang & & & & & & & & & & & Para pemain top Indonesia yang \\
\hline & direncanakan berlaga membela klub & & & & & & & & & & & direncanakan berlaga membela klub \\
\hline & yang membesarkan nama mereka & & & & & & & & & & & yang membesarkan nama mereka \\
\hline & adalah Kevin Sanjaya, Tontowi & & & & & & & & & & $\sqrt{ }$ & yaitu Kevin Sanjaya, Tontowi \\
\hline & Ahmad, Liliyana Natsir, Hendra & & & & & & & & & & $\mathrm{V}$ & Ahmad, Liliyana Natsir, Hendra \\
\hline & Setiawan, Mohammad Ahsan, Greysia & & & & & & & & & & & Setiawan, Mohammad Ahsan, \\
\hline & $\begin{array}{l}\text { Polli, dan masih banyak lagi. } \\
(19 / 12 / 2018)\end{array}$ & & & & & & & & & & & Greysia Polli, dan masih banyak \\
\hline 72. & Sedangkan kelas taruna U-19 setiap & & & & & & & & & & & Kelas taruna U-19 setiap tahunnya \\
\hline & $\begin{array}{l}\text { tahunnya mempertandingan nomor } \\
\text { perorangan. }(19 / 12 / 2018)\end{array}$ & & & & & & & & & & $\sqrt{ }$ & $\begin{array}{l}\text { mempertandingkan nomor } \\
\text { perorangan. }\end{array}$ \\
\hline 73. & Adalah tikungan nomor enam di & & & & & & & & & & & Tikungan nomor enam di Sirkuit \\
\hline & Sirkuit Jerez yang diberi nama Dani & & & & & & & & & & $\sqrt{ }$ & Jerez yang diberi nama Dani \\
\hline & Pedrosa. $(19 / 12 / 2018)$ & & & & & & & & & & & Pedrosa. \\
\hline 74. & Di Jerezlah Pedrosa meraih & & & & & & & & & & & Pedrosa meraih kemenangan \\
\hline & kemenangan pertamanya pada kelas & & & & & & & & & & $\sqrt{ }$ & pertamanya di Jerez pada kelas \\
\hline & $250 \mathrm{cc}$ du tahun $2005 .(19 / 12 / 2018)$ & & & & & & & & & & & $250 \mathrm{cc}$ di tahun 2005 \\
\hline 75. & $\begin{array}{l}\text { Mendukung gaya hidup yang terbawa } \\
\text { modernisasi salah satunya adalah }\end{array}$ & & & & & & & & & & $\sqrt{ }$ & $\begin{array}{l}\text { Mendukung gaya hidup yang } \\
\text { terbawa modernisasi salah satunya }\end{array}$ \\
\hline
\end{tabular}




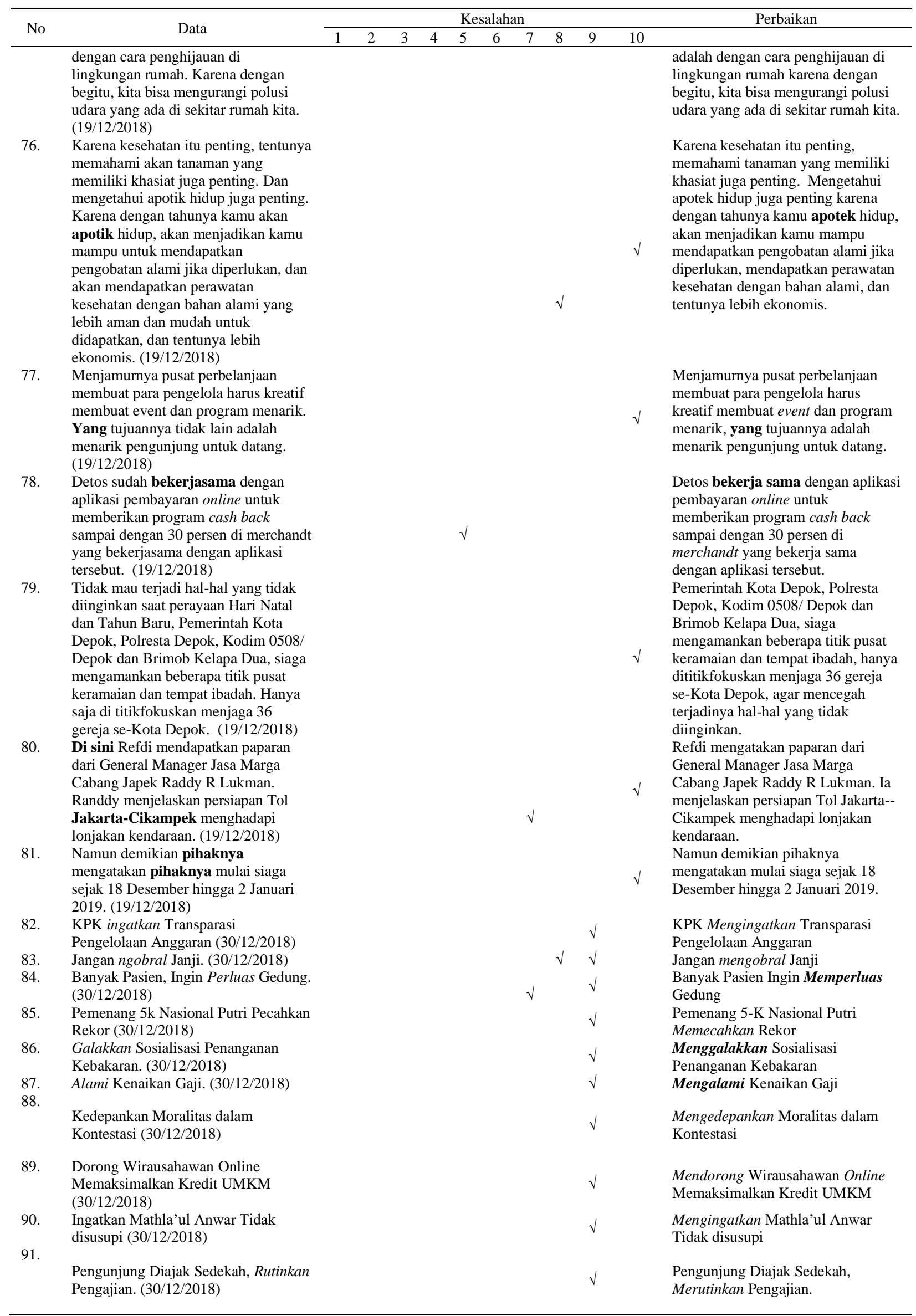




\begin{tabular}{|c|c|c|c|c|c|c|c|c|c|c|c|c|}
\hline \multirow{2}{*}{ No } & \multirow{2}{*}{ Data } & \multicolumn{10}{|c|}{ Kesalahan } & \multirow[t]{2}{*}{ Perbaikan } \\
\hline & & 1 & 2 & 3 & 4 & 5 & 6 & 7 & 8 & 9 & 10 & \\
\hline & TOTAL & 1 & 12 & 2 & 4 & 4 & 13 & 7 & 9 & 37 & 17 & 106 \\
\hline
\end{tabular}

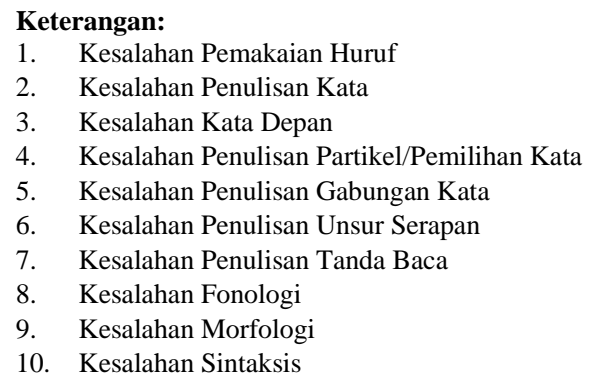

Tabel 2. Persentase Kesalahan Berbahasa pada Surat Kabar Harian Warta Kota

\begin{tabular}{clcc}
\hline No. & \multicolumn{1}{c}{ Jenis Kesalahan } & Jumlah & Persentase \\
\hline 1. & Pemakaian Huruf & 1 & $0,94 \%$ \\
2. & Penulisan Kata & 12 & $11,32 \%$ \\
3. & Penulisan Kata Depan & 2 & $1,89 \%$ \\
4. & Penulisan Partikel/Pemilihan Kata & 4 & $3,77 \%$ \\
5. & Penulisan Gabungan Kata & 4 & $3,77 \%$ \\
6. & Penulisan Unsur Serapan & 13 & $12,26 \%$ \\
7. & Penulisan Tanda Baca & 7 & $6,60 \%$ \\
8. & Fonologi & 9 & $8,49 \%$ \\
9. & Morfologi & 37 & $34,91 \%$ \\
10 & Sintaksis & 17 & $16,04 \%$ \\
& & $\mathbf{1 0 6}$ & $\mathbf{1 0 0 \%}$ \\
\hline
\end{tabular}

\section{Uraian dan Pembahasan}

Dari data di atas, berikut analisis yang akan diuraikan:

1. Kesalahan Pemakaian Huruf

Kesalahan pemakaian huruf pada data hanya ditemukan 1, yaitu pada penulisan dispendukcapil yang seharusnya menggunakan huruf kapital di awal karena merupakan akronim.

2. Kesalahan Penulisan Kata

Kesalahan penulisan kata yang ditemukan sebanyak 12. Pada penulisan Sekertaris, ruoanya, Mengganggur, Rerekonsiliasi, Sesaji terdapat kesalahan pengetikan (tipografi/typo) yang kemungkinan terjadi karena luput dari proses suntingan. Pada penulisan kata Peru-mahan, Ma-sih, Lalu-lintas mengalami kesalahan penggunaan tanda hubung yang seharusnya tidak perlu, sementara pada kata Terseok, terjadi kesalahan karena seharusnya diulang dan menggunakan tanda hubung (terseok-seok). Kesalahan penulisan berikutnya adalah pemenggalan dan penggabungan. Pada kata Langsungrekaman penulisan seharusnya dipenggal dan pada kata Di klaim dan Di diami penulisan seharusnya digabung.

3. Kesalahan Penulisan Kata Depan/Konjungsi

Kesalahan penulisan kata depan atau konjungsi ditemukan sebanyak 2, yaitu tapi dan karena itu. Sebagai konjungsi, penggunaan kata tapi di awal kalimat merupakan kesahanan karena seharusnya akan tetapi. Begitu pula dengan konjungsi karena itu yang merupakan konjungsi antarkalimat sehingga harus diperbaiki menjadi oleh karena itu.

4. Kesalahan Penulisan Partikel/Pemilihan Kata

Kata ngomong, bekas, dan syok dapat diganti dengan pemilihan kata berkata, mantan, dan trauma.

5. Kesalahan Penulisan Gabungan Kata 
Kesalahan penulisan gabungan kata ditemukan sebanyak 4, yaitu sedia kala, duka cita, pascagempa, bekerjasama. Kata sedia kala, duka cita, dan pasca-gempa ditulis serangkai tanpa tanda baca apapun karena merupakan gabungan kata yang antarpartikelnya tidak dapat berdiri sendiri. Sementara, penulisan gabungan kata bekerjasama harus dipisah karena merupakan gabungan kata yang antarpartikelnya dapat berdiri sendiri.

6. Kesalahan Penulisan Unsur Serapan

Kesalahan penulisan unsur serapan ditemukan sebanyak 13, yaitu shock, cesar, cabe, survey, Press release, unbankable, gate, skybridge, sample, Vertical, system, Beach, Base camp. Kata-kata tersebut harus ditulis cetak miring (italic) karena merupakan kata yang diserap dari bahasa lain.

7. Kesalahan Penulisan Tanda Baca

Kesalahan penulisan tanda baca ditemukan sebanyak 7, yaitu Serpong-Cinere, Kemendikbud-Tanoto, 'regrouping', 'ungkap, E- KTP, Banyak Pasien, Jakarta-Cikampek. Terdapat kesalahan penggunaan tanda hubung, seperti pada penulisan Serpong-Cinere, Kemendikbud-Tanoto, dan Jakarta-Cikampek. Seharusnya digunakan tanda pisah $(-)$ karena menunjukkan jarak dan yang berikutnya menyatakan keterangan apositif (tambahan). Kesalahan berikutnya adalah penggunaan tanda petik tunggal yang seharusnya tanda kutip (petik dua).

8. Kesalahan Fonologi

Kesalahan fonologi pada kata ngaku, ngotot, nyenangkan, pamerin, pecahin, nyindir, ngobral, apotik berupa penambahan fonem berupa akhiran (-in), penambahan fonem di awal (-ng, -ny), dan kesalahan fonem di tengah (apotik yang seharusnya apotek).

9. Kesalahan Morfologi

Kesalahan morfologi yang terjadi merupakan kesalahan paling banyak yang ditemukan. Kesalahan tersebut berupa kesalahan pada proses pembentukan kata.

a. Kata siapkan dalam kalimat Politisi Kebon Sirih Siapkan Empat Perda Inisiatif di 2019 merupakan bentuk kata dasar "Siap" yang mempuyai arti sudah disediakan, sudah selesai (dibuat atau dikerjakan). Seharusnya kata tersebut diberi imbuhan ber-, $m e N-$, peN-, pe-an, ke-an, dan $m e N-a n$ sehingga menjadi

Bersiap $\rightarrow$ Mempersiapkan $\rightarrow$ Menyiapkan $\rightarrow$ Penyiapan $\rightarrow$ Persiapan $\rightarrow$ Kesiapan. Kalimat tersebut seharusnya ditulis: Politisi Kebon Sirih Menyiapkan Empat Perda Inisiatif di 2019.

b. Kata Keluhkan dalam kalimat Warga Keluhkan Pembangunan Tower Sutet merupakan bentuk kesalahan morfologis karena kalimat tersebut merupakan kalimat aktif transitif. Menurut kaidah bahasa, predikat kalimat aktif transitif wajib berawalan meng- dan seharusnya kalimat tersebut ditulis Warga Mengeluhkan Pembangunan Tower Sutet.

c. Kata Ingatkan dalam kalimat KPK Ingatkan Transparasi Pengelolaan Anggaran merupakan bentuk kesalahan morfologis karena kalimat tersebut merupakan kalimat aktif transitif. Menurut kaidah bahasa, predikat kalimat aktif transitif wajib berawalan meng- dan seharusnya kalimat tersebut ditulis: KPK Mengingatkan Transparasi Pengelolaan Anggaran

d. Kata maksimalkan dalam kalimat Mendorong Wirausahawan Online Maksimalkan Kredit UMKM merupakan bentuk kata dasar "Maksimal" yang mempunyai arti sebanyak-banyaknya, setinggitingginya atau terbanyak. Seharusnya kata tersebut diberi imbuhan MeN-kan, ke-an sehingga kata tersebut menjadi Maksimal $\rightarrow$ Memaksimalkan $\rightarrow$ Kemaksimalan

Kalimat tersebut seharusnya ditulis: Mendorong Wirausahawan Online Memaksimalkan Kredit UMKM.

e. Kata "Ingatkan" dalam kalimat Ingatkan Mathla'ul Anwar Tidak Disusupi merupakan bentuk kata dasar "Ingat" yang mempuyai arti berada dalam pikiran. Seharusnya kata tersebut diberi imbuhan $m e N-$, dan peN- sehingga menjadi Ingat $\rightarrow$ Mengingat $\rightarrow$ Menginatkan $\rightarrow$ Peringatan $\rightarrow$ Memperingati $\rightarrow$...

Kalimat tersebut seharusnya ditulis Mengingatkan Mathla'ul Anwar Tidak Disusupi.

10. Kesalahan Sintaksis

Kesalahan sintaksis juga merupakan kesalahan terbanyak setelah kesalahan morfologis. Berikut adalah analisis kesalahan sintaksis. 
a. Tambahan tersebut terdiri dari penambahan 197 frekuensi penerbangan Garuda Indonesia dan 216 frekuensi penerbangan Citilink (5/11/2018). Pada kata penambahan tidak perlu ditulis kembali (dihilangkan).

b. Sejak duduk di bangku kuliah 2006 silam, guru SD Islam Al Fauzien ini sudah memulai karier pertamanya. Yakni, menjadi pengajar di tempat kursus untuk memenuhi kebutuhan selama menjalankan masa kuliah. (19/12/2018). Seharusnya kalimat pertama dan kedua dalam penulisannya menjadi satu kalimat.

c. Dengan peserta yang mengikuti kurang lebih 1.000 peserta dari tingkat SD-Perguruan Tinggi sejabodetabek. (19/12/2018) Kalimatnya kurang tepat dan adanya penjamakan ganda sehingga terjadinya pemborosan.

d. Namun, perguruan tinggi lama yang tidak bermutu, akan dilakukan merger. Sedangkan yang tidak melakukan pembelajaran dengan baik akan ditutup. (19/12/2018) Konjungsi seharusnya ditulis secara serangkai dengan kalimat sebelumnya.

e. Menteri Nasir membeberkan, ini namanya dinamika pendidikan. Tidak berarti kebijakan merger, tidak boleh mendirikan perguruan tinggi baru. (19/12/2018) Penjamakan ganda dalam satu kalimat sehingga diganti kata "bukan".

f. Junaedi Sitorus menambahkan, dengan dibentuknya DPW PPKLI DKI Jakarta, dia berharap agar para anggota PKL yang ada di DKI Jakarta dapat terorganisir dan tertera di bawah naungan mereka. (19/12/2018) Pemborosan kata dalam kalimat dan terdapat kata yang tidak baku.

g. Lembaga Pelaksana Pelatihan (LPP) Al Fattah mengadakan Workshop Peningkatan Mutu Lembaga yang membahas tentang kepemimpinan, Manajemen PAUD, dan kewirausahaan di Aula Gedung Perpustakaan Kota Depok. (19/12/2018) Penulisan bahasa asing harus dicetak miring atau bisa diganti dengan kata lokakarya atau lebih identik dengan seminar.

h. Para pemain top Indonesia yang direncanakan berlaga membela klub yang membesarkan nama mereka adalah Kevin Sanjaya, Tontowi Ahmad, Liliyana Natsir, Hendra Setiawan, Mohammad Ahsan, Greysia Polli, dan masih banyak lagi. (19/12/2018) Kesalahan dalam kalimat tersebut adalah ketidaktepatan pemilihan kata adalah.

i. Sedangkan kelas taruna U-19 setiap tahunnya mempertandingan nomor perorangan. (19/12/2018) Konjungsi pertentangan di dalam kalimat tidak digunakan di awal kalimat.

j. Adalah tikungan nomor enam di Sirkuit Jerez yang diberi nama Dani Pedrosa. (19/12/2018) Kesalahan ketidaktepatan penggunaan kata adalah dalam kalimat yang seharusnya dihilangkan.

k. Mendukung gaya hidup yang terbawa modernisasi salah satunya adalah dengan cara penghijauan di lingkungan rumah. Karena dengan begitu, kita bisa mengurangi polusi udara yang ada di sekitar rumah kita. (19/12/2018) Kesalahan pada konjungsi sebab.

1. Karena kesehatan itu penting, tentunya memahami akan tanaman yang memiliki khasiat juga penting. Dan mengetahui apotik hidup juga penting. Karena dengan tahunya kamu akan apotik hidup, akan menjadikan kamu mampu untuk mendapatkan pengobatan alami jika diperlukan, dan akan mendapatkan perawatan kesehatan dengan bahan alami yang lebih aman dan mudah untuk didapatkan, dan tentunya lebih ekonomis. (19/12/2018) Kesalahan pada konjungsi sebab, konjungsi koordinatif, frasa verbal, dan kata tidak baku.

m. Menjamurnya pusat perbelanjaan membuat para pengelola harus kreatif membuat event dan program menarik. Yang tujuannya tidak lain adalah menarik pengunjung untuk datang. (19/12/2018) Kesalahan pada kalimat efektif (kelogisan).

n. Tidak mau terjadi hal-hal yang tidak diinginkan saat perayaan Hari Natal dan Tahun Baru, Pemerintah Kota Depok, Polresta Depok, Kodim 0508/ Depok dan Brimob Kelapa Dua, siaga mengamankan beberapa titik pusat keramaian dan tempat ibadah. Hanya saja di titik fokuskan menjaga 36 gereja se-Kota Depok. (19/12/2018) Ketidaktepatan penempatan kalimat sehingga ada perubahan dan adanya kesalahan penulisan.

o. Di sini Refdi mendapatkan paparan dari General Manager Jasa Marga Cabang Japek Raddy R Lukman. Randdy menjelaskan persiapan Tol Jakarta-Cikampek menghadapi lonjakan kendaraan. (19/12/2018) Ketidaktepatan penggunaan kata di sini dalam kalimat. 


\section{Simpulan}

Penelitian yang dilakukan terhadap 12 surat kabar harian Warta Kota menghasilkan sejumlah data dan temuan tentang berbagai kesalahan berbahasa. Dari 12 surat kabar harian Warta Kota yang diteliti ditemukan sebanyak 91 kalimat mengalami kesalahan berbahasa.

Berdasarkan data, kesalahan berbahasa berdasarkan urutan terbesar sampai terkecil adalah kesalahan Morfologi (34,91\%); kesalahan Sintaksis (16,04\%); kesalahan Penulisan Unsur Serapan (12,26); kesalahan Penulisan Kata (11,32\%); kesalahan Fonologi (8,49\%); kesalahan Penulisan Tanda Baca (6,60\%); kesalahan Penulisan Partikel/Pemilihan Kata dan kesalahan Penulisan Gabungan Kata (3,77\%); kesalahan Penulisan Kata Depan (1,89\%); dan kesalahan Pemakaian Huruf (0,94\%).

\section{Ucapan Terima Kasih}

Terima kasih kepada LPPM Universitas Indraprasta PGRI, Tim Jurnal Hortatori, dan rekan dosen sejawat yang telah banyak memberikan masukan dan saran. Tidak lupa juga terima kasih kepada semua pihak yang tidak dapat kami sebutkan satu persatu yang telah berkontribusi dalam penelitian hingga pembuatan artikel ini.

\section{Daftar Rujukan}

Alber, Alber, and Hermaliza Hermaliza. "Kemampuan Menganalisis Kesalahan Berbahasa Mahasiswa Program Studi Pendidikan Bahasa Dan Sastra Indonesia Universitas Islam Riau.” Jurnal Sastra Indonesia 9.1 (2020): 1-10, doi:10.15294/jsi.v9i1.36366.

Chasanah, Nur Uswatun, et al. "Keterampilan Wartawan Dalam Penulisan Teras Berita Pada Koran Radar Madiun.” Widyabastra: Jurnal Ilmiah Pembelajaran Bahasa Dan Sastra Indonesia 2.1 (2018): 25-31, http://e-journal.unipma.ac.id/index.php/widyabastra/article/view/2090.

Nafilah, Ila, et al. "Morphological Errors in Skills Writing the Requirement of the Class Vocational School of Students Ceger Private Vocational Schooleast Jakarta." Hortatori : Jurnal Pendidikan Bahasa Dan Sastra Indonesia 2.2 (2019): 100-08, doi:10.30998/jh.v2i2.70.

Nasim, Eman Sulaeman. "Dampak Pengambilalihan Berita Kota Oleh Manajemen Warta Kota Terhadap Persaingan Bisnis Media Cetak Di Jakarta.” Transparansi: Jurnal Ilmiah Ilmu Administrasi 9.1 (2017): 69-86.

Nisa, Khairun. Analisis Kesalahan Berbahasa Pada Berita Dalam Media Surat Kabar Sinar Indonesia Baru. 2018, pp. 218-24.

Nurwicaksono, Bayu Dwi, and Diah Amelia. "Analisis Kesalahan Berbahasa Indonesia Pada Teks Ilmiah Mahasiswa." AKSIS: Jurnal Pendidikan Bahasa Dan Sastra Indonesia 2.2 (2018): 138-53, doi:10.21009/aksis.020201.

Rais, Ainun Rismawati Dewi, et al. "Analisis Kesalahan Berbahasa Mahasiswa IKIP Siliwangi Dalam Literasi Media." Parole (Jurnal Pendidikan Bahasa Dan Sastra Indonesia) 3.4 (2020): 505-14, https://journal.ikipsiliwangi.ac.id/index.php/parole/article/download/4882/pdf\#: :text= Menurut Mukhtar (2013) metode penelitian,dan teori untuk suatu penelitian.\&text=Data yang telah direkap dengan,status sosial media dan observasi.

Sebayang, Sri Kurnia Hastuti, and Anita Soleha Sofyan. "Analisis Kesalahan Berbahasa Pada Sosial Media Instagram Dalam Postingan, Komentar, Dan Cerita Singkat.” Jurnal Serunai Bahasa Indonesia 16. 1 (2019): 49-57, doi:10.37755/jsbi.v16i1.124.

Sutrisna, Deden. "Analisis Kesalahan Morfologi Bahasa Indonesia Dalam Surat Kabar Radar Majalengka Edisi 16 Dan 25 April 2016.” Diglosia 1.1 (2017): 151-64.

Utami, Sintowati Rini. "Pembelajaran Aspek Tata Bahasa Dalam Buku Pelajaran Bahasa Indonesia." AKSIS: Jurnal Pendidikan Bahasa Dan Sastra Indonesia 1.2 (2017): 189-203, doi:doi.org/10.21009/AKSIS.010203.

Wahyuni, Restu. "Analisis Kemampuan Komunikasi Verbal Menulis Wartawan Implikasinya Pada Citra Media Harian Lokal Di Kota Serang.” Jurnal Lontar 4.1 (2016): 1-14.

Wiyanti, Endang, et al. "Tipe-Tipe Kesalahan Sintaksis Pada Karangan Siswa Kelas XI SMA Bina Spora Mandiri Cigombong Bogor.” Deiksis 9.03 (2017): 300, doi:10.30998/deiksis.v9i03.680. 